\title{
Apigenin Retards Atherogenesis by Promoting ABCA1-Mediated Cholesterol Efflux and Suppressing Inflammation
}

\author{
Kun Ren ${ }^{a, b}$ Ting Jiang ${ }^{a}$ Hui-Fang Zhou ${ }^{b}$ Yin Liang $^{b}$ Guo-Jun Zhao \\ aDepartment of Histology and Embryology, Guilin Medical University, Guilin, 'Institute of Cardiovascular \\ Research, Key Laboratory for Atherosclerology of Hunan Province, University of South China, \\ Hengyang, China
}

\section{Key Words}

Atherosclerosis - ATP-binding cassette transporter A1 - Inflammation • Toll-like receptor 4 • Nuclear factor- $\mathrm{KB}$

\begin{abstract}
Background/Aims: The development of atherosclerosis is accompanied by escalating inflammation and lipid accumulation within blood vessel walls. ABCA1 plays a crucial role in mediating cholesterol efflux from macrophages, which protects against atherogenesis. This research was designed to explore the effects and underlying mechanisms of apigenin (4', 5, 7-trihydroxyflavone) on ABCA1-mediated cellular cholesterol efflux and LPS-stimulated inflammation in RAW264.7 macrophages and apoE ${ }^{-/-}$mice. Methods: Expression of genes or proteins was examined by RT-PCR or western blot analysis. Liquid scintillation counting was used to detect percent cholesterol efflux. Cellular cholesterol content was measured using HPLC assay. The secretion levels of pro-inflammatory cytokines were quantified by ELISA assay. Atherosclerotic lesion sizes were determined with Oil Red $O$ staining. The contents of macrophages and smooth muscle cells in atherosclerotic lesion were evaluated using immunohistochemistry. Plasma TC, TG, HDL-C and LDL-C levels in apoE evaluated using commercial test kits. Results: Apigenin potently increased ABCA1 expression through miR-33 repression in a dose- and time-dependent manner. Treatment with apigenin significantly increased ABCA1-mediated cholesterol efflux, and reduced TC, FC and CE levels in macrophage-derived foam cells. In LPS-treated macrophages, the expression levels of TLR-4, MyD88 and p-IкB- $\alpha$ as well as nuclear NF-KB p65 were decreased by the addition of apigenin. Moreover, apigenin markedly decreased secretion levels of several pro-inflammatory cytokines. Lastly, in LPS-challenged apoE $\mathrm{E}^{-/}$mice, apigenin administration augmented ABCA1 expression, decreased the contents of macrophages and smooth muscle cells in atherosclerotic lesion, reduced miR-33, TLR-4, and NF-KB p65 levels, improved plasma lipid profile and relieved inflammation, which results in less atherosclerotic lesion size. Conclusions: Taken together, these results suggest that apigenin may attenuate atherogenesis through up-regulating ABCA1-mediated cholesterol efflux and inhibiting inflammation.

K. Ren and T. Jiang contributed equally to this work.




\section{Cellular Physiology Cell Physiol Biochem 2018;47:2170-2184 \\ and Biochemistry Published onlıne: July 05, $2018 \quad \begin{aligned} & \text { DOI: 10.1159/000491528 } 2018 \text { The Author(s). Published by S. Karger AG, Basel } \\ & \text { www.karger.com/cpb }\end{aligned}$ \\ Ren et al.: Apigenin Promotes ABCA1 Expression and Suppresses Inflammation}

\section{Introduction}

Cardiovascular disease (CVD) is one of the common causes of mortality around the world [1], the pathophysiological foundation of which is atherosclerosis (AS) [2]. AS is widely considered as a chronic inflammatory disease driven by the deposition of lipid-laden macrophages within arterial walls [3]. Increasing evidence has revealed a close relationship between lipid disorder and inflammation, as observed in trauma or septic shock [4]. Progressive vascular inflammatory responses are crucial in the onset and development of AS and are closely associated with thrombotic complications [5].

The disruption of cholesterol homeostasis can induce lipid deposition in macrophages, leading to the formation of macrophage-derived foam cells and progression of AS [6]. ATP binding cassette $\mathrm{A} 1$ (ABCA1) can alleviate excessive lipid accumulation via accelerating cellular cholesterol efflux, which promotes macrophage reverse cholesterol transport (RCT) and high-density lipoproteins (HDL) formation. It has been proved that absence of ABCA1 in macrophages could exacerbate AS by restraining cholesterol efflux and aggravating plaque inflammation in vivo [7], while upregulation of ABCA1 can enhance cholesterol efflux and reduce lipid accumulation [8]. Thus, magnifying the expression level of ABCA1 in macrophages is an effective way in deterring atherogenesis [9].

Apigenin, a natural flavonoid compound, is ubiquitously present in various fruits and vegetables, such as grapefruits, oranges, celeries and onions [10]. Apigenin possesses high bioactivity and can exert many beneficial effects, including neuroprotection, antiproliferation, anti-anaphylaxis, anti-oxidation, anti-cancer and anti-inflammation $[11,12]$. Moreover, apigenin is reported to be instrumental in protecting against the development of AS. It can prevent oxidized low-density lipoprotein (ox-LDL)-induced endothelial monocyte adhesion and improve endothelial dysfunction via inhibiting LDL oxidation and endothelial ox-LDL uptake in the early stages of AS [13]. Zeng et al. revealed that apigenin attenuated atherogenesis through inducing apoptosis of ox-LDL-loaded murine peritoneal macrophages (MPMs) via down-regulation of plasminogen activator inhibitor 2 (PAI-2) in vivo [14]. Moreover, apigenin can lower the expression of pro-inflammatory cytokines and promote apoptosis of foam cells by inhibiting autophagy of foam cells during atherogenesis [15]. In addition, apigenin can impede AS development by decreasing serum cholesterol levels in the mouse model of hyperlipidemia, suggesting that apigenin is involved in the absorption and conversion of lipids [16]. These observations unraveled the critical roles of apigenin in lipid metabolism and athero-protection.

Toll-like receptors (TLRs), including TLR-2 and TLR-4, are involved in inflammation and the development of atherosclerotic plaques $[17,18]$. Most TLRs transmit their signals through its down-stream effector myeloid differentiation primary response gene 88 (MYD88), resulting in the activation of nuclear factor- $\kappa \mathrm{B}(\mathrm{NF}-\kappa \mathrm{B})$ transcription factor and subsequent expression of pro-inflammatory cytokines $[19,20]$. Mohan et al. reported that apigenin can repress autophagy and enhance apoptosis in neuroblastoma cells through TLR-4 and NF$\kappa B$ suppression [21]. Notably, apigenin can ameliorate inflammation through inhibition of TLR-4 and NF- $\kappa B$ activation. In a mouse model of lung ischemia-reperfusion injury (LIRI), apigenin administration significantly reduced NF- $\kappa \mathrm{B}$ activation and the expression levels of tumor necrosis factor- $\alpha$ (TNF- $\alpha$ ), interleukine-6 (IL-6), and inducible nitric oxide synthase (iNOS) [22]. Zhang et al. [23] demonstrated that apigenin could improve early brain injury (EBI) and protect against blood-brain barrier (BBB) disruption in subarachnoid hemorrhage rats by repressing TLR-4/NF- $\kappa B$ pathway-mediated inflammation. Given that $\mathrm{ABCA} 1$ expression can be repressed by pro-inflammatory stimulus via the NF- $\kappa \mathrm{B}$ signaling pathway [24], apigenin likely regulates ABCA1 expression and cholesterol metabolism. As such, we explored the effects and potential mechanisms of apigenin on ABCA1 expression, function and inflammation in macrophages and further atherogenesis in apoE $\mathrm{E}^{-/}$mice. Our results showed that apigenin can mitigate AS progression by magnifying ABCA1-mediated cholesterol efflux through miR-33 repression, and relieving inflammation via inhibition of TLR-4/NF- $\kappa$ B pathway. 


\section{Cellular Physiology Cell Physiol Biochem 2018;47:2170-2184 \begin{tabular}{ll|l} 
and Biochemistry Published onlıne: July 05, 2018 & $\begin{array}{l}\text { C } 2018 \text { The Author(s). Published by S. Karger AG, Basel } \\
\text { www.karger.com/cpb }\end{array}$ \\
\hline
\end{tabular}

\section{Materials and Methods}

\section{Cell culture and treatment}

Mouse RAW264.7 cells from the Type Culture Collection of the Chinese Academy of Sciences (Shanghai, China) were cultured in Dulbecco's modified Eagle's medium (DMEM) supplemented with $10 \%$ fetal bovine serum (FBS) and 1\% penicillin/streptomycin in a constant-temperature incubator with a humidified atmosphere of $5 \% \mathrm{CO}_{2}$ at $37^{\circ} \mathrm{C}$.

\section{RNA extraction and real-time PCR (RT-PCR)}

Total RNA was extracted using the TRIzol reagent (Invitrogen) according to the manufacturer's instructions, followed by reverse transcription using a TaqMan Reverse Transcription Reagents Kit (Applied Biosystems). RT-PCR was conducted on a Roche Light Cycler Run 5.32 Real-Time PCR System using SYBR Green detection chemistry. The primer sequences are as follows: ABCA1 sense, 5'-AACAGTTTGTGGCCCTTTTG3'and anti-sense, 5'-AGTTCCAGGCTGGGGTACTT-3'; TLR-4 sense, 5'-AGTTTAGAGAATCTGGTGGCTGTG-3' and anti-sense, 5'-TTCCCTGAAAGGCTTGGTCT-3'; MyD88 sense, 5'-CCAGCGAGCTAATTGAGAAAAG-3' and antisense 5'-ATAGTGATGAACCGCAGGATAC-3'; $\beta$-actin forward, 5'-CCTAGAAGCATTTGCGGTGG-3' and reverse, 5'-GAGCTACGAGCTGCCTGACG-3'. All PCR products were evaluated by melt curve analyses, in which DNA duplexes were generated. Quantitative measurements were achieved using the ${ }^{{ }^{⿴ 囗 十}} \mathrm{Ct}$ method and $\beta$-actin level was used as the internal control. For miRNA assays, total RNA was obtained from macrophages using miRVana miRNA isolation kit (Life Technologies) and then reverse transcribed by standard real-time qPCR (Applied Biosystems). The miR-33 level was determined using the TaqMan microRNA assay kit for miR-33 (Applied Biosystems). U6 RNA was used as an internal control.

\section{Western blot analysis}

Cells or murine tissues were used for protein extraction (for detection of ABCA1, TLR-4, IкB- $\alpha$,

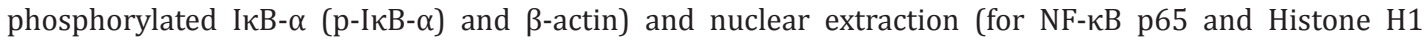
measurement) as previously described [25]. A BCA assay kit (CWBIO, Peking, China) was used to quantify protein concentrations. Proteins ( $20 \mu \mathrm{g}$ per lane) were loaded on an $8 \%$ SDS-polyacrylamide electrophoresis gel (SDS-PAGE, Solarbio Co, Peking, China), electrophoresed and fractionated at $120 \mathrm{~V}$ for $1.5 \mathrm{~h}$ in gel running buffer. Subsequently, they were electroblotted onto immobilon-P transfer membranes (Merck Millipore, Darmstadt, Germany), the efficiency of which was assessed by Li Chunhong S staining (CWBIO, Peking, China). Afterwards, membranes were incubated in blocking agent (5\% fat-free milk in TBS-T) for 4 $\mathrm{h}$ at room temperature and then immunoblotted with primary antibodies against ABCA1, TLR-4, NF- $\mathrm{kB}$ p65, IкB- $\alpha, p$-IкB- $\alpha, \beta$-actin and Histone H1 (Sigma-Aldrich, Inc. USA) with gentle shaking at $4^{\circ} \mathrm{C}$ overnight. After rinsed four times in TBS-T (for 10, 10, 5, and $5 \mathrm{~min}$, respectively), membranes were further incubated with a peroxidase-conjugated secondary antibody (Abcam, Cambridge, UK) in TBS-T for $2 \mathrm{~h}$ at room temperature. Finally, proteins were visualized using a chemiluminescence method (enhanced chemiluminescence Plus Western Blotting Detection System; Amersham Biosciences, Foster City, CA) and the levels were determined semi-quantitatively using Quantity One software.

\section{High-performance liquid chromatography (HPLC) assay}

HPLC assay was performed according to the following protocols: cells were washed with PBS several times, followed by addition of $1 \mathrm{ml}$ of $0.5 \% \mathrm{NaCl}$ to $100-200 \mu \mathrm{g}$ cellular proteins (per ml). Then, cells were sonicated for $3 \mathrm{~min}$ using an ultrasonic processor. A BCA kit was used to determine protein concentrations in cell solution. An equivalent volume of freshly prepared cold $\mathrm{KOH}$ (dissolved in $150 \mathrm{~g} / \mathrm{L}$ ethanol, $-20^{\circ} \mathrm{C}$ ) was added. Cell lysates were vortexed several times until clear. An equal bulk of hexane isopropanol: 3:2 $(\mathrm{v} / \mathrm{v})$ was then supplemented. After vortexed for $5 \mathrm{~min}$, the mixture was centrifuged at $800 \mathrm{rpm}$ at $15^{\circ} \mathrm{C}$ for $8 \mathrm{~min}$. The procedure of extraction was repeated five times. Afterwards, approximately $0.1 \mathrm{ml}$ of aliquot cell solution (containing 5 20 $\mu \mathrm{g}$ protein) was used to detect free cholesterol $(\mathrm{FC})$ and another aliquot for total cholesterol (TC) measurement. Isopropanol was used to dissolve FC (1 $\mathrm{mg}$ cholesterol/ml), which was subsequently stored at $-20^{\circ} \mathrm{C}$ as a stock solution. Cholesterol standard calibration solution $(0 \sim 40 \mu \mathrm{g}$ cholesterol/ml) was prepared by dilution of the cholesterol stock solutions.

Thereafter, $0.1 \mathrm{ml}$ of each sample (cell solutions, or cholesterol standard calibration solutions) was supplemented with $10 \mu \mathrm{l}$ reaction mixture (including $10 \mathrm{mM}$ dithiothreitol, $5 \% \mathrm{NaCl}, 500 \mathrm{mM} \mathrm{MgCl}$, and 


\section{Cellular Physiology Cell Physiol Biochem 2018;47:2170-2184 \begin{tabular}{l|l} 
and Biochemistry Published 10.1159/000491528 & $\begin{array}{l}\text { (c) } 2018 \text { The Author(s). Published by S. Karger AG, Basel } \\
\text { www.karger.com/cpb }\end{array}$ \\
\hline
\end{tabular} \\ Ren et al.: Apigenin Promotes ABCA1 Expression and Suppresses Inflammation}

$500 \mathrm{mM}$ Tris-HCl (pH 7.4)). Approximately 0.4 unit of cholesterol oxidase in $10 \mu \mathrm{l} 0.5 \% \mathrm{NaCl}$ was added to each tube for FC detection, or 0.4 unit of cholesterol oxidase plus 0.4 unit of cholesterol esterase for TC measurement. The reaction process was conducted at $37^{\circ} \mathrm{C}$ for $30 \mathrm{~min}$ and then stopped by addition of 100 $\mu \mathrm{l}$ of ethanol: methanol (1:1). Each tube was placed in chilling condition for $30 \mathrm{~min}$ to accelerate protein precipitation, and then centrifuged at $15^{\circ} \mathrm{C}$ at $1500 \mathrm{rpm}$ for $12 \mathrm{~min}$. Then, the supernatant ( $\left.10 \mu \mathrm{l}\right)$ was applied onto a System Chromatographer (PerkinElmer Inc.), including a pump, a PerkinElmer series 200 vacuum degasser, a PerkinElmer series 600 LINK, a PerkinElmer series 200 UV/vies detector, and a Discovery C-18 HLPC column (Supercool Inc.). Column elution was performed using isopropanol: n-heptane: acetonitrile (35:13:52) at a flow rate of $1 \mathrm{ml} / \mathrm{min}$ for $10 \mathrm{~min}$. Data were evaluated using TotalChrom software from PerkinElmer with absorbance at $216 \mathrm{~nm}$ [26].

\section{MiR-33 and anti-miR-33 transfection}

Mouse RAW264.7 macrophages were transfected with $40 \mathrm{nM}$ miRIDIAN miRNA mimics (miR-33) or with $60 \mathrm{nM}$ miRIDIAN miRNA inhibitors (anti-miR-33) (Dharmacon) utilizing Oligofectamine (Invitrogen). The control groups were treated with an equivalent concentration of a non-targeting control mimics sequence (Con miR) or inhibitor negative control sequence (Con Inh) for non-sequence-specific effects. After 48h, miR-33 overexpression and knockdown were verified using RT-PCR, as described above [27].

\section{Cholesterol efflux assay}

Cholesterol efflux was analyzed as previously described [28]. Briefly, RAW264.7 macrophage-derived foam cells were seeded into 6 -well plates $\left(1 \times 10^{6}\right.$ cells/well). On day 3 , cells were radiolabeled with $0.5 \mu \mathrm{Ci} /$ $\mathrm{ml}$ of $\left[{ }^{3} \mathrm{H}\right]$-cholesterol (PerkinElmer, Waltham, MA) for $24 \mathrm{~h}$ in media supplemented with $0.2 \%$ bovine serum albumin (BSA). On the following day, equilibrated $\left[{ }^{3} \mathrm{H}\right]$ cholesterol-labeled cells were washed with fresh media and subsequently treated conditionally as shown in the figures. Then, cells were washed again with PBS and cultured in media containing apoA-I $(10 \mu \mathrm{g} / \mathrm{mL})$ for $24 \mathrm{~h}\left[{ }^{3} \mathrm{H}\right]$.-cholesterol in cells and medium were then detected using liquid scintillation counting. Percent efflux was evaluated according to the equation: [total media counts/ (total cellular counts + total media counts)] $\times 100 \%$.

\section{Small interfering RNA}

RAW264.7 macrophages $\left(1 \times 10^{6}\right.$ cells/well) were transfected with small-interfering RNA (siRNA) specific for ABCA1 (Santa Cruz Biotechnology, sense, 5'-CCAAAUGGCUCUGUGUAUAUU-3' and anti-sense, 5'-UAUACACAGAGCCAUUUGGUU-3') using Lipofectamine 2000 (Invitrogen) following the manufacturer's instructions. $48 \mathrm{~h}$ later, western blot analysis was performed to evaluate ABCA1 protein level [29].

\section{Cytokine ELISA}

Cells were seeded into 6 -well plates $\left(1 \times 10^{6}\right.$ cells/well $)$ with and without treatments as indicated in the figures. Cell supernatants were harvested and stored at $-20^{\circ} \mathrm{C}$ for further analysis. The concentrations of interleukine-1 $\beta$ (IL-1 $\beta$ ), IL-6 and tumor necrosis factor- $\alpha$ (TNF- $\alpha$ ) in the supernatants were determined by ELISA assay (DuoSet ELISA Development System, R\&D Systems, Abingdon, UK) in accordance with the manufacturer's instructions. Standard curves were generated using the cytokine standards. Quantitative measurements were performed based on three different experiments [29].

\section{Mice and treatments}

ApoE ${ }^{-/}$mice (male, six-week old) were obtained from Laboratory Animal Center of Peking University in China and fed a chow diet for 2 weeks. Then, eight-week-old apoE $\%$ mice were fed a high-fat diet and randomly divided into several groups ( $n=15$ /group). In the following 8 weeks, mice in the LPS group were administered intraperitoneally (i.p.) with LPS $(2.5 \mathrm{mg} / \mathrm{kg}$ body wt, dissolved in $200 \mu \mathrm{l}$ of PBS) once every week. An equivalent bulk of PBS was injected into the control group. The apigenin group was intragastrically given apigenin (10 mg/kg body wt) every day based on LPS treatment. At week 16, mice were euthanized, and blood and tissue samples were harvested for further detection.

The procedure strictly followed the Guide for the Care and Use of Laboratory Animals published by the US National Institutes of Health (NIH publication no. 85-23, revised in 1996) and Care and Use guidelines for experimental animals of the University of South China. The investigation protocol was approved by the Animal Ethics Committee of University of South China. Prior to surgeries, all mice were given sodium pentobarbital anesthesia to minimize sufferings. 


\section{Cellular Physiology Cell Physiol Biochem 2018;47:2170-2184 \begin{tabular}{l|l} 
and Biochemistry Published $10.1159 / 000491528$ & $\begin{array}{l}\text { C } 2018 \text { The Author(s). Published by S. Karger AG, Basel } \\
\text { www.karger.com/cpb }\end{array}$
\end{tabular} \\ Ren et al.: Apigenin Promotes ABCA1 Expression and Suppresses Inflammation}

\section{Serum lipid analyses}

After mice were fasted overnight and sacrificed, serum samples were obtained from the retro-orbital plexus. Plasma TC, triglyceride (TG), HDL cholesterol (HDL-C) and LDL cholesterol (LDL-C) levels were measured by enzymatic methods using commercial test kits (Shanghai Rongsheng Biotech Inc. Shanghai, China).

Assessment of aortic lesions

Hearts and proximal aortas were obtained and fixed in 4\% paraformaldehyde. Under and parallel to the leaflet, hearts were cut directly, the upper sections of which were embedded in OCT medium and stored at $4^{\circ} \mathrm{C}$. Then, aortic sinus was cleaved and six $\mu \mathrm{m}$ thick segments were obtained. Twenty or more segments of each mouse were stained using Oil Red 0 and further counter-stained with Gill III hematoxylin (Sigma). Atherosclerotic lesion size was analyzed using IMAGEPRO PLUS (Media Cybnetics, Silver Spring, MD). Data were presented as lesion size \pm SEM [30].

\section{Immunohistochemistry}

The contents of macrophages and smooth muscle cells (SMCs) in atherosclerotic lesion were measured using immunohistochemistry [31]. Briefly, sections were blocked with $0.3 \%_{2} \mathrm{H}_{2}(30 \mathrm{~min})$ and 5\% BSA (Sigma) $(1 \mathrm{~h})$. Then, they were probed with anti-CD68 antibody (1:200, ProteinTech Group, Inc, USA) or anti- $\alpha$-SMA antibody (1:200, ProteinTech Group, Inc, USA) overnight at $4^{\circ} \mathrm{C}$. Slides were washed and further exposed to biotin-conjugated goat anti-rabbit $\lg \mathrm{G}$ for $1 \mathrm{~h}$ at room temperature. Following a series of rinses, slides were developed with 3, 3'-diaminobenzidine (1/10, DAB Quanto Kit, TA-060-QHDX, ThermoFisher) and then counterstained with hematoxylin. Photographs were taken using a microscope at $200 \times$ magnification.

\section{Statistical analysis}

All data are expressed as the means \pm standard deviation (SD) from at least three independent experiments. Results were analyzed by one-way analysis of variance and Student's t-test using the SPSS 13.0 software. $\mathrm{P}<0.05$ was considered statistically significant.

\section{Results}

Apigenin stimulates ABCA1 expression and ABCA1-mediated cholesterol efflux from RAW264.7 macrophages-derived foam cells

The formation and deposition of foam cells within blood vessel walls are the key events in the development of AS [32]. ABCA1 can prevent foam cell formation by exporting excessive cholesterol from lipid-loaded macrophages and maintain cellular lipid and cholesterol homeostasis [33]. Firstly, we examined the effects of apigenin on macrophage ABCA1 expression and ABCA1-mediated cholesterol efflux. RAW264.7 macrophages were pre-treated with $50 \mu \mathrm{g} / \mathrm{ml}$ ox-LDL for $48 \mathrm{~h}$ to fully differentiate into foam cells, followed by incubation with various concentrations $(0,10,20,40 \mu \mathrm{M})$ of apigenin for $24 \mathrm{~h}$. As shown in Fig. 1A, apigenin increased ABCA1 mRNA level in a dose-dependent manner. Next, cells were incubated with apigenin $(40 \mu \mathrm{M})$ for different time periods (for $0,6,12,24 \mathrm{~h}$, respectively) to detect whether apigenin enhances ABCA1 expression in a time-dependent manner. As shown in Fig. 1B, ABCA1 transcriptional level was increased gradually with increasing duration of apigenin treatment. Similar phenomena were observed using western blot analysis to measure ABCA1 protein level (Figs. 1C and D). Furthermore, HPLC and liquid scintillation counting assays showed that apigenin incubation concentration- and timedependently reduced cholesterol contents, including TC, FC and cholesterol ester (CE) levels, in macrophages-derived foam cells (Tables 1 and 2), whereas it facilitated cellular cholesterol efflux (Figs. 2A and B). When ABCA1 expression was knocked down by siRNA transfection (Fig. 2C), the effect of apigenin on cholesterol efflux was abolished (Fig. 2D). These observations suggest that apigenin can inhibit foam cell formation by enhancing ABCA1 expression and ABCA1-mediated cholesterol efflux. 
Fig. 1. Effects of apigenin on ABCA1 expression in RAW264.7 macrophages. RAW264.7 macrophages were pre-treated with $50 \mu \mathrm{g} / \mathrm{ml}$ ox-LDL for $48 \mathrm{~h}$ to fully differentiate into foam cells. Then, they were incubated with different concentrations of apigenin $(0,10,20,40 \mu \mathrm{M})$ for $24 \mathrm{~h}$ or apigenin $(40 \mu \mathrm{M})$ for various time periods (for $0,6,12,24 \mathrm{~h}$, respectively). RT-PCR and western blot analyses were performed to measure the mRNA (A, B) and protein (C, D) levels of ABCA1, respectively. All values were obtained from three independent experiments, each performed in triplicate. Data were presented as means \pm SD. $* \mathrm{P}<0.05$ vs control group.

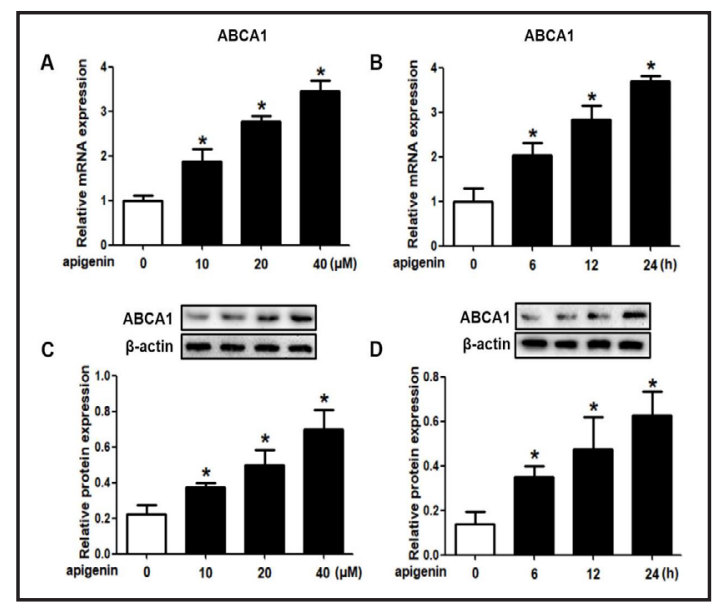

Fig. 2. Effects of apigenin on cholesterol efflux from RAW264.7 macrophage-derived foam cells. RAW264.7 macrophages were pre-treated with $50 \mu \mathrm{g} / \mathrm{ml}$ ox-LDL for $48 \mathrm{~h}$ to fully differentiate into foam cells. A, B. Cells were treated with different concentrations $(0,10,20,40 \mu \mathrm{M})$ of apigenin for $24 \mathrm{~h}$ or various time periods $(0,6,12,24 \mathrm{~h})$ of apigenin $(40 \mu \mathrm{M})$, then apoA-I $(10 \mu \mathrm{g} / \mathrm{ml})$ was added to the medium as a lipid acceptor for another $6 \mathrm{~h}$. Percent cholesterol efflux was evaluated by liquid scintillation counting assay as described above. ${ }^{*} \mathrm{P}<0.05$ vs control group. C, D. After cells were transfected with ABCA1 siRNA for $48 \mathrm{~h}$, apigenin and/or apoA-I were added.

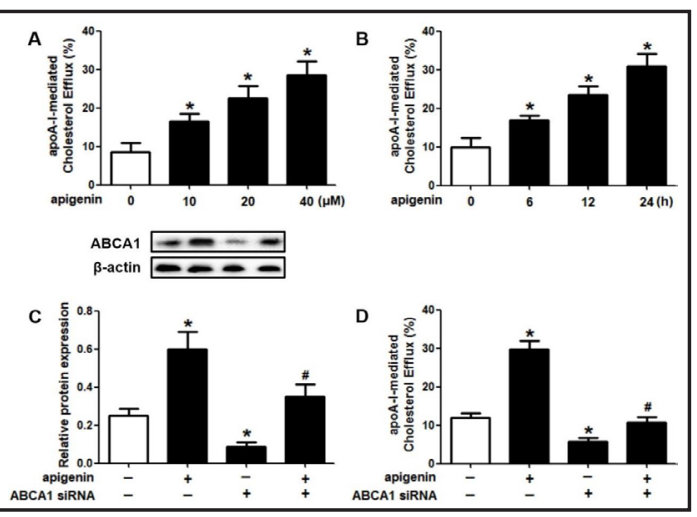
Then, western blot and liquid scintillation counting assay were conducted. All values were obtained from three independent experiments, each performed in triplicate. Data were reported as means $\pm \mathrm{SD}$. $* \mathrm{P}<0.05 \mathrm{vs}$ control group, ${ }^{~} \mathrm{P}<0.05$ vs apigenin only group.

The stimulatory effects of apigenin on ABCA1 expression and cholesterol efflux were mediated by miR-33 repression

The previous study has demonstrated that ABCA1 expression can be negatively regulated by miR-33 [34, 35]. Here, we examined whether miR-33 is involved in the augmentation of apigenin on ABCA1 expression and cholesterol efflux. RAW264.7 macrophages-derived foam cells were incubated with different concentrations or incubation times of apigenin, followed by RT-PCR determination of apigenin effects on miR-33 expression. Results showed that apigenin treatment significantly repressed miR-33 expression in both concentrationand time-dependent manners (Figs. $3 \mathrm{~A}$ and B). Then, we performed gain- or lossof-function experiments to further confirm
Table 1. Effects of various concentrations of apigenin on cholesterol contents in RAW264.7 macrophagederived foam cells. TC, total cholesterol; FC, free cholesterol; CE, cholesteryl ester; ${ }^{*}$ compared with control group, $\mathrm{p}<0.05$

\begin{tabular}{lcccc}
\hline Apigenin $(\mu \mathrm{M})$ & 0 & 10 & 20 & 40 \\
\hline TC $(\mathrm{mg} / \mathrm{g})$ & $775 \pm 12$ & $684 \pm 22^{*}$ & $556 \pm 18^{*}$ & $413 \pm 27^{*}$ \\
FC $(\mathrm{mg} / \mathrm{g})$ & $314 \pm 15$ & $266 \pm 13^{*}$ & $218 \pm 24^{*}$ & $161 \pm 14^{*}$ \\
CE $(\mathrm{mg} / \mathrm{g})$ & $461 \pm 24$ & $418 \pm 11^{*}$ & $338 \pm 26^{*}$ & $252 \pm 28^{*}$ \\
CE $/ \mathrm{TC}(\%)$ & 59.5 & 61.1 & 60.8 & 61.0 \\
\hline
\end{tabular}

Table 2. Time-dependent effects of apigenin on cholesterol contents in RAW264.7 macrophagederived foam cells. TC, total cholesterol; FC, free cholesterol; CE, cholesteryl ester; ${ }^{*}$ compared with control group, $\mathrm{p}<0.05$

\begin{tabular}{lcccc}
\hline Apigenin (h) & 0 & 6 & 12 & 24 \\
\hline TC (mg/g) & $733 \pm 16$ & $641 \pm 12^{*}$ & $551 \pm 25^{*}$ & $433 \pm 21^{*}$ \\
FC (mg/g) & $298 \pm 13$ & $255 \pm 19^{*}$ & $212 \pm 23^{*}$ & $166 \pm 29^{*}$ \\
CE (mg/g) & $435 \pm 25$ & $386 \pm 22^{*}$ & $339 \pm 17^{*}$ & $267 \pm 11^{*}$ \\
CE/TC (\%) & 59.3 & 60.2 & 61.5 & 61.6 \\
\hline
\end{tabular}




\section{Cellular Physiology \begin{tabular}{l|l} 
DOI: 10.1159/000491528 & $\begin{array}{l}\text { O } 2018 \text { The Author(s). Published by S. Karger AG, Basel } \\
\text { www.karger.com/cpb }\end{array}$
\end{tabular} \\ Ren et al.: Apigenin Promotes ABCA1 Expression and Suppresses Inflammation}

Fig. 3. MiR-33 is involved in the positive effects of apigenin on ABCA1 expression and cholesterol efflux.RAW264.7 macrophages were pre-incubated with $50 \mu \mathrm{g} / \mathrm{ml}$ ox-LDL for $48 \mathrm{~h}$ to fully differentiate into foam cells. A, B. Cells were incubated with various concentrations of apigenin $(0,10,20$, $40 \mu \mathrm{M}$ ) for $24 \mathrm{~h}$ or $40 \mu \mathrm{M}$ apigenin for different time periods $(0,6,12,24 \mathrm{~h})$, RT-PCR was used to measure mRNA levels of miR-33. ${ }^{*} \mathrm{P}<0.05$ vs control group. C-H. After cells were transfected with miR33 mimic or anti-miR-33, apigenin and/or apoA-I were added. Then, RT-PCR, western blot and liquid scintillation counting assays were performed. All results were from three independent experiments, each performed in triplicate. Data were presented as means $\pm \mathrm{SD} .{ }^{*} \mathrm{P}<0.05$ vs control group. ${ }^{*} \mathrm{P}<0.05$ vs apigenin only group.

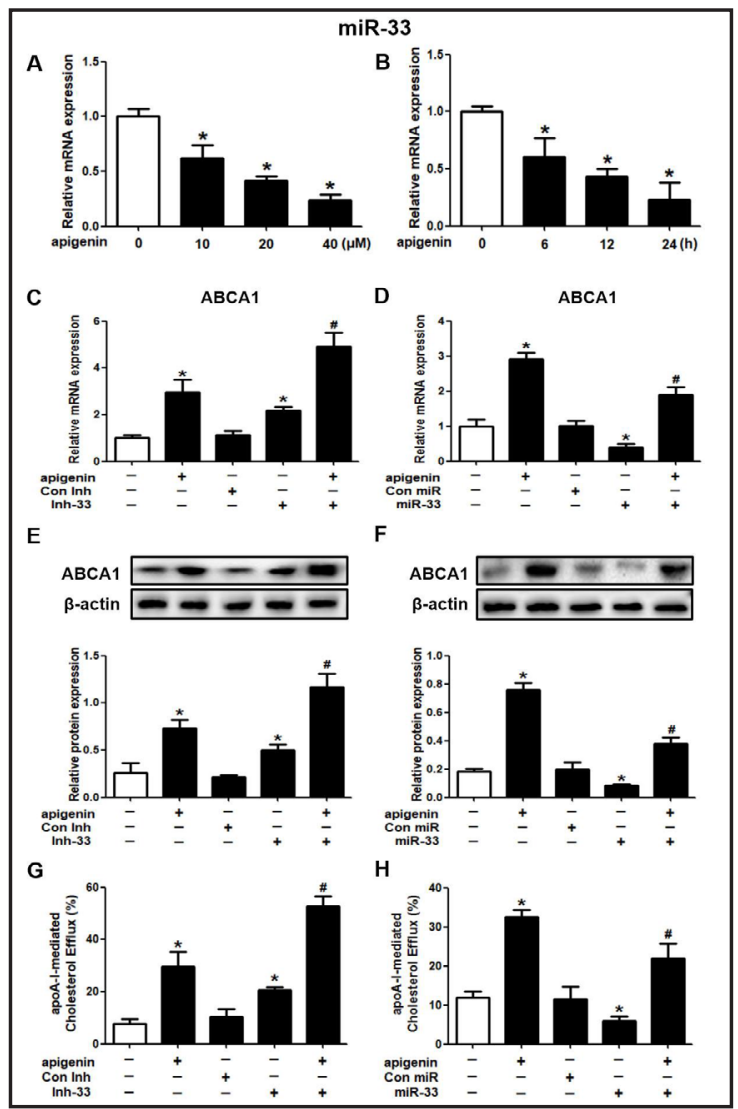

the functional role of miR-33 in apigenin-induced ABCA1 expression. As shown in Figs. 3 $\mathrm{C}, \mathrm{E}$ and $\mathrm{G}$, the stimulatory effects of apigenin on ABCA1 expression and cholesterol efflux were enhanced by miR-33 inhibitor (anti-miR-33) transfection in RAW264.7 macrophages. Conversely, transfection of macrophages with miR-33 mimic blocked the magnification of apigenin on ABCA1 expression as well as ABCA1-mediated cholesterol efflux (Figs. 3 D, F and $\mathrm{H})$. These results suggest that apigenin enhances ABCA1 expression and cholesterol efflux via miR-33 inhibition.

\section{Apigenin inhibits the activation of TLR-4/NF- $K B$ pathway in macrophages}

AS is a lipid-driven inflammatory disorder. Chronic vascular inflammation is closely related to AS development [36]. Previous studies have revealed that apigenin can protect against inflammation $[22,23]$. Thus, we examined the effects of apigenin on LPS-stimulated inflammation in RAW264.7 macrophages. As shown, apigenin potently decreased LPSinduced augmentation of TLR-4 and MyD88 expression at both mRNA and protein levels (Figs. 4 A, B and C). Furthermore, apigenin incubation significantly ruled out the magnifying effects of LPS on nuclear NF- $\mathrm{BB}$ p65 protein levels (Fig. 4 D). The phosphorylation, ubiquitination, and proteolytic degradation of I $\kappa \mathrm{B}-\alpha$ are followed by NF- $\kappa \mathrm{B}$ translocation to the nucleus. To determine the involvement of I $\kappa \mathrm{B}-\alpha$ in apigenin-induced NF- $\kappa \mathrm{B}$ inhibition, we used western blot analysis to examine IкB- $\alpha$ status in the cytoplasm. Results showed that apigenin-treated cells displayed a significant decrease in p-IкB- $\alpha$ level (Figs. $4 \mathrm{~A}$ and $B)$, which was consistent with the decreased nuclear accumulation of NF- $\kappa B$ p65 protein. Lastly, we examined the effects of apigenin on LPS-stimulated secretion of pro-inflammatory cytokines in macrophages. As shown in Figs. 4 E-G, apigenin significantly inhibited LPSinduced production of IL-1 $\beta$, IL- 6 and TNF- $\alpha$. Taken together, these findings suggest that apigenin suppresses inflammation in LPS-treated macrophages via inhibiting TLR-4/NF- $\kappa B$ signaling pathway. 


\section{Cellular Physiology Cell Physiol Biochem 2018;47:2170-2184 \begin{tabular}{l|l} 
DOI: 10.1159/000491528 & $\begin{array}{l}\text { O } 2018 \text { The Author(s). Published by S. Karger AG, Basel } \\
\text { www.karger.com/cpb }\end{array}$
\end{tabular} \\ Ren et al.: Apigenin Promotes ABCA1 Expression and Suppresses Inflammation}

Apigenin decreases atherosclerotic lesions and the contents of macrophages and SMCS within atherosclerotic plaques in apoE $\%$ mice

Apigenin has been found to effectively improve alcohol-induced liver injury in mice without obvious toxicity [37]. As increased cellular cholesterol efflux and decreased levels of pro-inflammatory cytokines can impede atherogenesis, we determined the effects of apigenin on atherosclerotic lesion sizes and plaque composition in apoE $\mathrm{E}^{-/}$mice. Oil Red 0 and immunohistological staining showed that the lesion sizes and contents of macrophages and SMCs within aortic plaques in LPS-challenged apoE $/$ mice were significantly increased compared to PBS-treated group [25]. Moreover, apigenin administration obviously reduced lesion sizes and contents of macrophages and SMCs within aortic plaques compared with those injected with LPS alone (Figs. $5 \mathrm{~A}$-D). It has been proved that inflammation and infection are associated with increased serum TC and TG levels in rodents [38]. Thus, we measured these serum parameters in apigenin-treated apoE ${ }^{-/}$mice (Table 3). The serum TC and TG levels were significantly lower in the apigenin-treated group than those in LPS-injected mice. Further analysis of the plasma lipoproteins showed a reduction in LDL and an enhancement in HDL cholesterol levels in apigenin-administered mice, suggesting that apigenin-induced repression of AS is, at least partially, via modulation of plasma lipoprotein cholesterol levels. The results are consistent with our in vitro findings that apigenin increased macrophage ABCA1 expression and cholesterol efflux.

Fig. 4. Apigenin inhibits activation of the TLR$4 / \mathrm{NF}-\kappa \mathrm{B}$ pathway in LPS-treated macrophages. RAW264.7 macrophages were treated with LPS (100 ng/ml) for $24 \mathrm{~h}$. A, B. The protein levels of TLR4, MyD88, IкB- $\alpha, \mathrm{p}-\mathrm{I} \kappa \mathrm{B}-\alpha$ were detected by western blot analysis. C. Transcriptional levels of TLR-4 and MyD88 were determined with RT-PCR. D. The protein level of NF- $\kappa$ B p65 in nuclear extracts was evaluated. E-G, ELISA assay was used to evaluate IL-1 $\beta$, IL- 6 and TNF- $\alpha$ levels in the medium. All results were obtained from three independent experiments, each performed in triplicate. Values were expressed as means $\pm \mathrm{SD}$. ${ }^{*} \mathrm{P}<0.05$ vs control

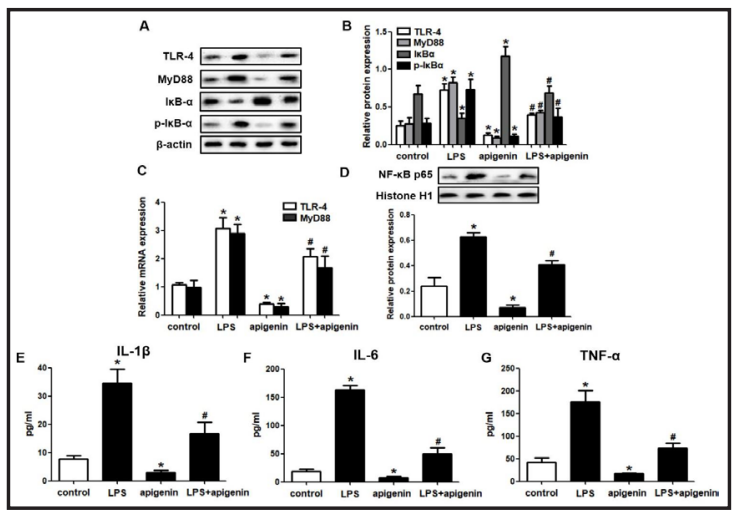
group; ${ }^{\mathrm{P}<0.05}$ vs LPS only group.

Fig. 5. Effects of apigenin on the expression levels of miR-33, ABCA1 and atherosclerotic lesions in apoE $/$ mice. Eight-week-old apoE ${ }^{-/-}$mice were administered with PBS, LPS (2.5 mg/kg body wt) or LPS (2.5 mg/ $\mathrm{kg}$ body wt) plus apigenin (10 mg/kg body wt) for eight weeks. A. Representative images of Oil Red 0 staining of aortic sinus lesion. Original magnification: $\times 40$. B. Macrophages content was detected by immunohistological staining against CD68. Original magnification: $\times 200$. C. SMC content was evaluated by immunohistological staining against $\alpha$-SMA. Original magnification: $\times 200$. D. quantification of the lesion size in mice ( $n=15 /$ group). Data were expressed as means \pm SEM. $*$ P $<0.05$. E. MiR-33 level in the aorta was determined by RT-PCR. F. ABCA1 protein level in the aorta was measured using western blot. Values are expressed as means \pm SD ( $n=3 /$ group). ${ }^{*} \mathrm{P}<0.05$ vs LPS only group.

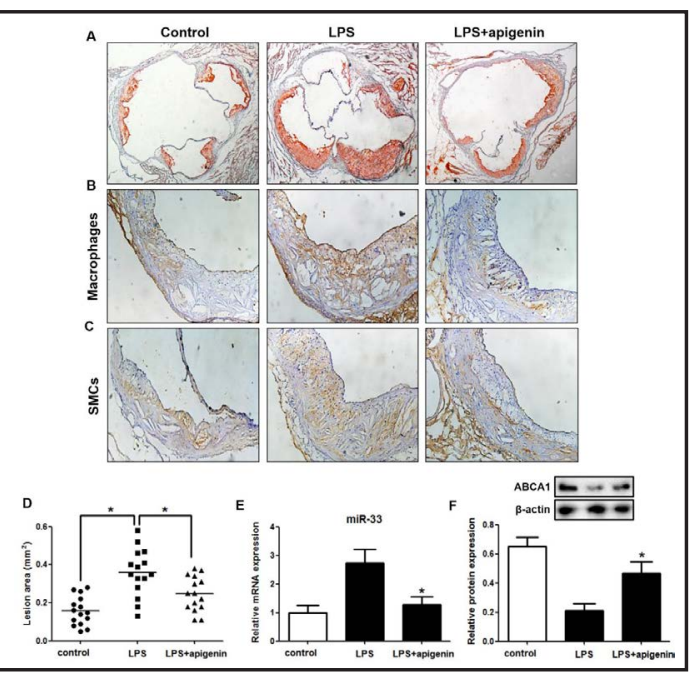




\section{Cellular Physiology Cell Physiol Biochem 2018;47:2170-2184 \begin{tabular}{l|l} 
DOI: 10.1159/000491528 & Ond Biochemistry 2018 The Author(s). Published by S. Karger AG, Basel \\
www.karger.com/cpb
\end{tabular} Ren et al.: Apigenin Promotes ABCA1 Expression and Suppresses Inflammation}

Fig. 6. Effects of apigenin on the expressions levels of TLR-4, NF- $\kappa$ B p65, IL-1 $\beta$, IL- 6 and TNF- $\alpha$ in apoE $\mathrm{E}^{-/-}$mice. Eight-week-old male apoE $\mathrm{E}^{-/-}$mice were ad libitum divided into three groups as described above. A, B. TLR-4 and NF- $\kappa$ B p65 levels in the homogenate of aortic arch were detected by western blot analysis. C-E, Serum IL-1 $\beta$, IL- 6 and TNF- $\alpha$ levels were determined using ELISA assay. Data were expressed as mean \pm SD ( $n=3$ /group). $* \mathrm{P}<0.05$ vs LPS only group.

\section{Apigenin regulates lipid metabolism} and inflammation in vivo

According to the results above, we evaluated whether apigenin could modulate miR-33/ABCA1, TLR-4 and $\mathrm{NF}-\kappa \mathrm{B}$ expressions in vivo. As shown in Figs. $5 \mathrm{E}$ and $\mathrm{F}$, apigenin remarkably decreased miR-33 level and promoted ABCA1 expression in the aorta compared with those mice injected with LPS alone, suggesting that the increase in plasma HDL-C level and diminution in atherosclerotic lesions induced by apigenin administration may be ascribed to ABCA1 enhancement. Additionally, we found that apigenin injection decreased the expression levels of aorta TLR-4 and NF- $\mathrm{B}$ p 65, leading to reduced plasma pro-inflammatory cytokines levels (Fig. 6). These observations are in line with our in vitro data on the beneficial effects of apigenin and support the notion that apigenin can augment ABCA1 expression and suppress inflammation in vivo.

\section{Discussion}

In this study, we explored the athero-protective effects of apigenin and the molecular mechanisms underlying apigenin-induced cholesterol efflux and anti-inflammation in RAW264.7 macrophages and further atherosclerotic lesions in apo: $\%$ mice. Apigenin, a less toxic and non-mutagenic flavonoid compound, can attenuate atherosclerotic plaque development by promoting ABCA1-mediated cholesterol efflux via miR-33 inhibition, and reducing pro-inflammatory cytokine secretion through repression of the TLR-4/NF- $\kappa B$ pathway. Fig. 7 is a graphic illustration of the mechanisms.

AS is characterized by progressive vascular lesion formation caused by excessive lipid accumulation and chronic inflammatory response within arterial walls, followed by diverse kinds of cardiovascular complications [39]. Macrophages, which are derived from monocytes, can release inflammatory factors and aggravate AS. Redundant uptake of lipoproteins or decreased cholesterol efflux can induce cholesterol-laden macrophages and then the formation of foam cells, which also accelerates the development of atherosclerotic lesions $[3,7]$. In view of these pathophysiological mechanisms, researchers are eager to seek safe and effective remedies to improve macrophage cholesterol homeostasis and inflammation for AS treatment.

Apigenin is distributed ubiquitously in a wide range of vegetables, fruits and medicinal plants as well as dietary and herbal supplements [37, 40]. Recently, apigenin has drawn much attention for its powerful medicinal properties, including anti-tumor, anti-virus, anti- 


\section{Cellular Physiology Cell Physiol Biochem 2018;47:2170-2184 \begin{tabular}{l|l} 
and Biochemistry 10.1159/000491528 & $\begin{array}{l}\text { O 2018 The Author(s). Published by S. Karger AG, Basel } \\
\text { www.karger.com/cpb }\end{array}$
\end{tabular}

Fig. 7. Schematic illustration of the effects of apigenin on miR-33/ABCA1-dependent cholesterol efflux and TLR-4/NF- $\kappa$ B pathway-mediated inflammation. The present study has unraveled the following mechanisms: On one hand, apigenin treatment represses miR-33 expression, whereby it augments ABCA1 expression and ABCA1-mediated cholesterol efflux to apoA-I, a process that promotes HDL formation and regression of AS. On the other hand, apigenin inhibits LPS-stimulated activation of TLR4 and MyD88, and subsequent IкB phosphorylation as well as NF- $\kappa \mathrm{B}$ p65 translocation, leading to

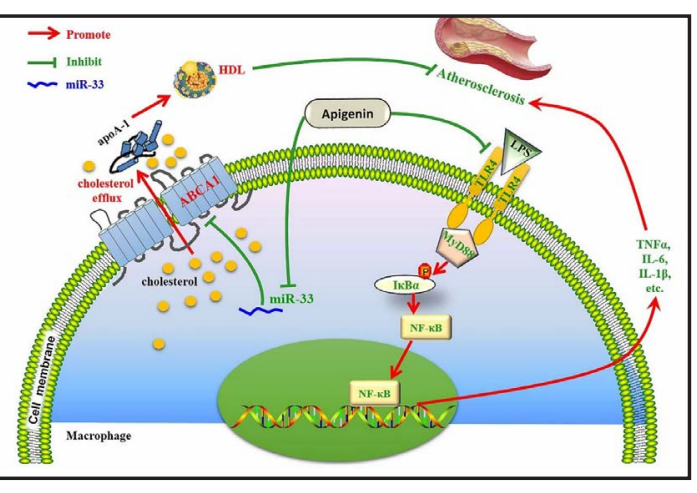
decreased secretion levels of IL-1 $\beta$, IL- 6 and TNF- $\alpha$ and suppression of AS. Altogether, apigenin plays a critical role in the mitigation of atheromatous plaque size. Green texts: inhibition; red texts: promotion.

bacteria, anti-oxidation, and anti-inflammation. Shan et al. [41] reported that apigenin can significantly block colon cancer development by inhibiting tumor-specific pyruvate kinase M2 (PKM2)-mediated cellular glycolysis. Tu et al. found that apigenin can remarkably improve cognitive deficits after reperfusion injury and cerebral ischemia via inhibition of histone deacetylase (HDAC) and promotion of brain-derived neurotrophic factor (BDNF) as well as synapsin-I (Syn-I) [42]. Another study by Fallatah 0 and his co-workers demonstrated the feasibility of apigenin on the therapy of plasmodium falciparum (P. falciparum) infectioninduced malarias [43]. They established that apigenin can promote ABCC1-mediated glutathione efflux from P. falciparum infected erythrocytes and impede parasite proliferation. In the cardiovascular system, Li et al. [44] found that apigenin can protect against endotoxininduced myocardial injury and improve cardiac function by regulating oxidative stress and inflammation in vivo. In myocardial ischemia/reperfusion (I/R) mice, treatment with apigenin decreased infarct size and the release of lactate dehydrogenase (LDH) and creatine kinase (CK). Further studies showed that apigenin enhanced total superoxide dismutase (SOD) activity and reduced malondialdehyde (MDA) content in myocardium via repression of p38 MAPK signaling pathway, suggesting that apigenin can prevent cardiomyocytes from I/R-induced injury. Thus far, the studies regarding the athero-protective effects of apigenin and the underlying molecular mechanisms are limited to a certain extent $[14,15]$. Many kinds of flavonoid can exert athero-protection through regulation of lipid and cholesterol metabolism and macrophage ABCA1 expression [45-47], which makes us wonder whether apigenin can inhibit atherogenesis by maintaining cholesterol homeostasis. The results showed that treatment of lipid-laden macrophages with apigenin markedly increased cholesterol efflux and decreased cholesterol content by amplifying ABCA1 expression in a concentration- and time-dependent manner. Furthermore, in line with other studies, apigenin treatment significantly alleviated LPS-stimulated inflammation in macrophages, supporting the protective role of apigenin in atherogenesis.

MiRNAs are short, conserved nonprotein-coding RNAs responsible for expression regulation of target genes. Through association with the 3' untranslated region (3' UTR) of mRNA transcripts, they can repress protein translation or induce mRNA degradation [48]. Many studies have unraveled the key role of miRNAs in regulating AS development [49, 50]. Our previous study established that betulinic acid (BA), a pentacyclic triterpenoid, can stimulate ABCA1 expression and cholesterol efflux through inhibition of NF- $\kappa B$ signaling and miR-33. Here, we found that apigenin can potently decrease miR-33 expression level in a concentration- and time-dependent manner in RAW264.7 macrophages. In addition, the increase in ABCA1 expression and cholesterol efflux induced by apigenin is augmented by miR-33 inhibitor transfection and eliminated by miR-33 mimic transfection, respectively. These observations suggest that the stimulatory effects of apigenin on ABCA1 expression and cholesterol efflux are mediated by miR-33 suppression. Most recently, evidence showed 


\section{Cellular Physiology Cell Physiol Biochem 2018;47:2170-2184 \begin{tabular}{l|l} 
DOI: 10.1159/000491528 & $\begin{array}{l}\text { O 2018 The Author(s). Published by S. Karger AG, Basel } \\
\text { www.karger.com/cpb }\end{array}$ \\
\cline { 2 - 3 }
\end{tabular} \\ Ren et al.: Apigenin Promotes ABCA1 Expression and Suppresses Inflammation}

that apigenin can influence lipid metabolism by activating PPAR $\gamma$ [51]. As PPAR $\gamma /$ LXR $\alpha$ pathway has been well demonstrated in the regulation of ABCA1 expression $[6,52,53]$, this pathway may also be responsible for apigenin-induced up-regulation of ABCA1 expression and cholesterol efflux, which still warrants further investigation.

In addition to lipid disorder, persistent and chronic inflammation within vessel walls also gives a great impetus to AS progression [54]. A large body of research has demonstrated that NF- $\mathrm{KB}$ and TLR-4 activities are closely associated with lipid metabolism, inflammation and progression of AS [55-58]. In the absence of TLR-4, the innate immune and inflammatory responses were inhibited and atheromatous plaque sizes were diminished [59-61]. NF$\kappa \mathrm{B}$ is a well-known downstream effector of TLR-4, and suppression of LPS-induced NF- $\kappa B$ signaling attenuates atherogenesis [62]. Luo et al. [63] observed that pycnogenol, another kind of flavonoid compound, can decrease lipid droplet formation and mitigate LPStriggered atherosclerotic development by repressing TLR4/NF- $\kappa B$ pathway in human THP-1 monocytes. Liang et al. found that phosphatase receptor type 0 (PTPRO) plays an unfavorable role in atherogenesis by stimulating ox-LDL-induced cell apoptosis and oxidative stress through activation of the TLR4/NF- $\kappa$ B pathway in RAW264.7 macrophages [64]. Based on these findings, we hypothesized that TLR-4/NF- $\kappa B$ pathway may be implicated in apigenininduced athero-protection. Results showed that treatment of LPS-stimulated RAW264.7 macrophages with apigenin significantly reduced TLR-4 and MyD88 expression at both mRNA and protein levels. Besides, apigenin incubation decreased cytoplasmic phosphorylation of I $\kappa \mathrm{B}-\alpha$ and then nuclear expression of NF- $\kappa \mathrm{B}$ p65. Moreover, the secretion levels of proinflammatory cytokines, including IL-1 $\beta$, IL- 6 and TNF- $\alpha$, which are likely influenced by TLR-4/NF- $\mathrm{BB}$ pathway, are reduced markedly following the treatment of apigenin. These results suggest that apigenin exhibits anti-inflammatory effects through inhibition of TLR4/MyD88-mediated NF- $\kappa B$ translocation. Considering that ABCA1 and miR-33 expression levels are regulated by NF- $\kappa B$ activity $[32,65]$, TLR-4/NF- $\kappa B$ pathway may also be involved in apigenin-induced ABCA1 expression and cholesterol efflux. Lastly, we detected the effects of apigenin on atherosclerotic lesion sizes and plaque composition in apoE $\mathrm{E}^{-/-}$mice. Compared with the LPS only group, apigenin-injected mice displayed less lesion sizes and contents of macrophages and SMCs within aortic plaques, decreased miR-33, TLR-4 and NF- $\kappa B$ p65 and increased ABCA1 levels in the aorta. Plasma TC, TG, LDL-C, IL-1 $\beta$, IL- 6 and TNF- $\alpha$ levels were reduced while HDL-C level was augmented. These parameters are in line with our in vitro observations and confirm the effects and underlying mechanisms of apigenin-induced antiatherogenesis.

In conclusion, our experiments have provided evidence that apigenin can retard AS aggravation by promoting ABCA1-mediated cholesterol efflux via miR-33 suppression, and relieving inflammation through suppression of the TLR-4/NF- $\kappa B$ signaling pathway. Our findings have shed new light on the therapeutic application of this promising phytomedicine for AS prevention.

\section{Acknowledgements}

This work is financially sponsored by the National Natural Sciences Foundation of China (81660082), the Guangxi Natural Sciences Foundation (AA139209), Autonomous region College Students' innovation and entrepreneurship training program (201610601047), Hunan Provincial Innovation Foundation For Postgraduate (CX2017B503), Hunan Provincial Natural Science Foundation of China (14JJ2091), and Zhengxiang scholar program (prof. Xiangyang Tang) of the University of South China.

\section{Disclosure Statement}

No conflict of interests exists. 


\section{Cellular Physiology Cell Physiol Biochem 2018;47:2170-2184 \begin{tabular}{l|l} 
and Biochemistry Published onlıne: July 05, 2018 & $\begin{array}{l}\text { (c) } 2018 \text { The Author(s). Published by S. Karger AG, Basel } \\
\text { www.karger.com/cpb }\end{array}$
\end{tabular}

\section{References}

1 Yamashita T, Sasaki N, Kasahara K, Hirata K: Anti-inflammatory and immune-modulatory therapies for preventing atherosclerotic cardiovascular disease. J Cardiol 2015;66:1-8.

-2 Rafieian-Kopaei M, Setorki M, Doudi M, Baradaran A, Nasri H: Atherosclerosis: process, indicators, risk factors and new hopes. Int J Prev Med 2014;5:927-946.

3 Moore KJ, Sheedy FJ, Fisher EA: Macrophages in atherosclerosis: a dynamic balance. Nat Rev Immunol 2013;13:709-721.

-4 Stoll G, Bendszus M: Inflammation and atherosclerosis: novel insights into plaque formation and destabilization. Stroke 2006;37:1923-1932.

-5 Wang Z, Nakayama T: Inflammation, a link between obesity and cardiovascular disease. Mediators Inflamm 2010;2010:535918.

-6 Lin XL, Hu HJ, Liu YB, Hu XM, Fan XJ, Zou WW, Pan YQ Zhou WQ Peng MW, Gu CH: Allicin induces the upregulation of ABCA1 expression via PPARgamma/LXRalpha signaling in THP-1 macrophage-derived foam cells. Int J Mol Med 2017;39:1452-1460.

7 Westerterp M, Murphy AJ, Wang M, Pagler TA, Vengrenyuk Y, Kappus MS, Gorman DJ, Nagareddy PR, Zhu X, Abramowicz S, Parks JS, Welch C, Fisher EA, Wang N, Yvan-Charvet L, Tall AR: Deficiency of ATP-binding cassette transporters A1 and G1 in macrophages increases inflammation and accelerates atherosclerosis in mice. Circ Res 2013;112:1456-1465.

-8 Kuang HJ, Zhao GJ, Chen WJ, Zhang M, Zeng GF, Zheng XL, Tang CK: Hsp27 promotes ABCA1 expression and cholesterol efflux through the PI3K/PKCzeta/Sp1 pathway in THP-1 macrophages. Eur J Pharmacol 2017;810:57-62.

-9 Fu Y, Zhao Y, Huang B: Tribbles homolog 1 enhances cholesterol efflux from oxidized low-density lipoprotein-loaded THP-1 macrophages. Exp Ther Med 2017;14:862-866.

10 Sung B, Chung HY, Kim ND: Role of Apigenin in Cancer Prevention via the Induction of Apoptosis and Autophagy. J Cancer Prev 2016;21:216-226.

11 Anusha C, Sumathi T, Joseph LD: Protective role of apigenin on rotenone induced rat model of Parkinson's disease: Suppression of neuroinflammation and oxidative stress mediated apoptosis. Chem Biol Interact 2017;269:67-79.

12 Yu W, Sun H, Zha W, Cui W, Xu L, Min Q Wu J: Apigenin Attenuates Adriamycin-Induced Cardiomyocyte Apoptosis via the PI3K/AKT/mTOR Pathway. Evid Based Complement Alternat Med 2017;2017:2590676.

13 Jeong YJ, Choi YJ, Choi JS, Kwon HM, Kang SW, Bae JY, Lee SS, Kang JS, Han SJ, Kang YH: Attenuation of monocyte adhesion and oxidised LDL uptake in luteolin-treated human endothelial cells exposed to oxidised LDL. Br J Nutr 2007;97:447-457.

14 Zeng P, Liu B, Wang Q, Fan Q, Diao JX, Tang J, Fu XQ, Sun XG: Apigenin Attenuates Atherogenesis through Inducing Macrophage Apoptosis via Inhibition of AKT Ser473 Phosphorylation and Downregulation of Plasminogen Activator Inhibitor-2. Oxid Med Cell Longev 2015;2015:379538.

15 Wang Q, Zeng P, Liu Y, Wen G, Fu X, Sun X: Inhibition of autophagy ameliorates atherogenic inflammation by augmenting apigenin-induced macrophage apoptosis. Int Immunopharmacol 2015;27:24-31.

-16 Zhang K, Song W, Li D, Jin X: Apigenin in the regulation of cholesterol metabolism and protection of blood vessels. Exp Ther Med 2017;13:1719-1724.

-17 Suzuki K, Kawakami Y, Yamauchi K: Impact of TLR 2, TLR 4-activation on the Expression of ABCA1 and ABCG1 in Raw Cells. Ann Clin Lab Sci 2017;47:436-446.

18 Yang K, Liu X, Liu Y, Wang X, Cao L, Zhang X, Xu C, Shen W, Zhou T: DC-SIGN and Toll-like receptor 4 mediate oxidized low-density lipoprotein-induced inflammatory responses in macrophages. Sci Rep 2017;7:3296.

19 Hu L, Yang H, Ai M, Jiang S: Inhibition of TLR4 alleviates the inflammation and apoptosis of retinal ganglion cells in high glucose. Graefes Arch Clin Exp Ophthalmol 2017; 255: 2199-2210.

20 Han J, Zou C, Mei L, Zhang Y, Qian Y, You S, Pan Y, Xu Z, Bai B, Huang W, Liang G: MD2 mediates angiotensin II-induced cardiac inflammation and remodeling via directly binding to Ang II and activating TLR4/NFkappaB signaling pathway. Basic Res Cardiol 2017;112:9.

21 Mohan N, Banik NL, Ray SK: Combination of N-(4-hydroxyphenyl) retinamide and apigenin suppressed starvation-induced autophagy and promoted apoptosis in malignant neuroblastoma cells. Neurosci Lett 2011;502:24-29. 


\section{Cellular Physiology Cell Physiol Biochem 2018;47:2170-2184 and Biochemistry Published \begin{tabular}{l|l} 
DOI: 10.1159/000491528 & $\begin{array}{l}\text { C } 2018 \text { The Author(s). Published by S. Karger AG, Basel } \\
\text { www.karger.com/cpb }\end{array}$
\end{tabular} \\ Ren et al.: Apigenin Promotes ABCA1 Expression and Suppresses Inflammation}

-22 Bougioukas I, Didilis V, Emmert A, Jebran AF, Waldmann-Beushausen R, Stojanovic T, Schoendube FA, Danner BC: Apigenin Reduces NF-kappaB and Subsequent Cytokine Production as Protective Effect in a Rodent Animal Model of Lung Ischemia-Reperfusion Injury. J Invest Surg 2017:1-11.

23 Zhang T, Su J, Guo B, Wang K, Li X, Liang G: Apigenin protects blood-brain barrier and ameliorates early brain injury by inhibiting TLR4-mediated inflammatory pathway in subarachnoid hemorrhage rats. Int Immunopharmacol 2015;28:79-87.

24 Baranova I, Vishnyakova T, Bocharov A, Chen Z, Remaley AT, Stonik J, Eggerman TL, Patterson AP: Lipopolysaccharide down regulates both scavenger receptor B1 and ATP binding cassette transporter A1 in RAW cells. Infect Immun 2002;70:2995-3003.

25 Yin K, Tang SL, Yu XH, Tu GH, He RF, Li JF, Xie D, Gui QJ, Fu YC, Jiang ZS, Tu J, Tang CK: Apolipoprotein A-I inhibits LPS-induced atherosclerosis in ApoE(-/-) mice possibly via activated STAT3-mediated upregulation of tristetraprolin. Acta Pharmacol Sin 2013;34:837-846.

-26 Tian GP, Chen WJ, He PP, Tang SL, Zhao GJ, Lv YC, Ouyang XP, Yin K, Wang PP, Cheng H, Chen Y, Huang SL, Fu Y, Zhang DW, Yin WD, Tang CK: MicroRNA-467b targets LPL gene in RAW 264.7 macrophages and attenuates lipid accumulation and proinflammatory cytokine secretion. Biochimie 2012;94:2749-2755.

27 Rayner KJ, Suarez Y, Davalos A, Parathath S, Fitzgerald ML, Tamehiro N, Fisher EA, Moore KJ, FernandezHernando C: MiR-33 contributes to the regulation of cholesterol homeostasis. Science 2010;328:15701573.

28 Yu XH, Jiang HL, Chen WJ, Yin K, Zhao GJ, Mo ZC, Ouyang XP, Lv YC, Jiang ZS, Zhang DW, Tang CK: Interleukin-18 and interleukin-12 together downregulate ATP-binding cassette transporter A1 expression through the interleukin-18R/nuclear factor-kappaB signaling pathway in THP-1 macrophage-derived foam cells. Circ J 2012;76:1780-1791.

29 Yin K, Deng X, Mo ZC, Zhao GJ, Jiang J, Cui LB, Tan CZ, Wen GB, Fu Y, Tang CK: Tristetraprolin-dependent post-transcriptional regulation of inflammatory cytokine mRNA expression by apolipoprotein A-I: role of ATP-binding membrane cassette transporter A1 and signal transducer and activator of transcription 3 J Biol Chem 2011;286:13834-13845.

-30 Pang S, Tsuchiya S, Horie S, Uchida M, Murayama T, Watanabe K: Enhancement of phenylephrine-induced contraction in the isolated rat aorta with endothelium by H2O-extract from an Oriental medicinal plant Leonuri herba. Jpn J Pharmacol 2001;86:215-222.

-31 Liu XX, Zhang XW, Wang K, Wang XY, Ma WL, Cao W, Mo D, Sun Y, Li XQ: Kuwanon G attenuates atherosclerosis by upregulation of LXRalpha-ABCA1/ABCG1 and inhibition of NFkappaB activity in macrophages. Toxicol Appl Pharmacol 2018;341:56-63.

32 Zhao GJ, Mo ZC, Tang SL, Ouyang XP, He PP, Lv YC, Yao F, Tan YL, Xie W, Shi JF, Wang Y, Zhang M, Liu D, Tang DP, Zheng XL, Tian GP, Tang CK: Chlamydia pneumoniae negatively regulates ABCA1 expression via TLR2Nuclear factor-kappa B and miR-33 pathways in THP-1 macrophage-derived foam cells. Atherosclerosis 2014;235:519-525.

-33 Schumacher T, Benndorf RA: ABC Transport Proteins in Cardiovascular Disease-A Brief Summary. Molecules 2017;22.

-34 Lai L, Azzam KM, Lin WC, Rai P, Lowe JM, Gabor KA, Madenspacher JH, Aloor JJ, Parks JS, Naar AM, Fessler MB: MicroRNA-33 Regulates the Innate Immune Response via ATP Binding Cassette Transporter-mediated Remodeling of Membrane Microdomains. J Biol Chem 2016;291:19651-19660.

-35 He J, Zhang G, Pang Q Yu C, Xiong J, Zhu J, Chen F: SIRT6 reduces macrophage foam cell formation by inducing autophagy and cholesterol efflux under ox-LDL condition. FEBS J 2017;284:1324-1337.

-36 Wang Y, Han Z, Fan Y, Zhang J, Chen K, Gao L, Zeng H, Cao J, Wang C: MicroRNA-9 Inhibits NLRP3 Inflammasome Activation in Human Atherosclerosis Inflammation Cell Models through the JAK1/STAT Signaling Pathway. Cell Physiol Biochem 2017;41:1555-1571.

37 Wang F, Liu JC, Zhou RJ, Zhao X, Liu M, Ye H, Xie ML: Apigenin protects against alcohol-induced liver injury in mice by regulating hepatic CYP2E1-mediated oxidative stress and PPARalpha-mediated lipogenic gene expression. Chem Biol Interact 2017;275:171-177.

-38 Khovidhunkit W, Kim MS, Memon RA, Shigenaga JK, Moser AH, Feingold KR, Grunfeld C: Effects of infection and inflammation on lipid and lipoprotein metabolism: mechanisms and consequences to the host. J Lipid Res 2004;45:1169-1196.

-39 Yu XH, Fu YC, Zhang DW, Yin K, Tang CK: Foam cells in atherosclerosis. Clin Chim Acta 2013;424:245-252. 


\section{Cellular Physiology Cell Physiol Biochem 2018;47:2170-2184 \begin{tabular}{l|l} 
DOI: 10.1159/000491528 & $\begin{array}{l}\text { O } 2018 \text { The Author(s). Published by S. Karger AG, Basel } \\
\text { www.karger.com/cpb }\end{array}$ \\
and Biochemistry Published online: July 05, 2018
\end{tabular}

40 Zhang Q, Zhou MM, Chen PL, Cao YY, Tan XL: Optimization of ultrasonic-assisted enzymatic hydrolysis for the extraction of luteolin and apigenin from celery. J Food Sci 2011;76:C680-685.

41 Shan S, Shi J, Yang P, Jia B, Wu H, Zhang X, Li Z: Apigenin Restrains Colon Cancer Cell Proliferation via Targetedly Blocking the PKM2-dependent Glycolysis. J Agric Food Chem 2017 20; 65:8136-8144.

-42 Tu F, Pang Q, Huang T, Zhao Y, Liu M, Chen X: Apigenin Ameliorates Post-Stroke Cognitive Deficits in Rats Through Histone Acetylation-Mediated Neurochemical Alterations. Med Sci Monit 2017;23:4004-4013.

-43 Fallatah 0, Georges E: Apigenin-induced ABCC1-mediated efflux of glutathione from mature erythrocytes inhibits the proliferation of plasmodium falciparum. Int J Antimicrob Agents 2017; 50:673-677.

-44 Li F, Lang F, Zhang H, Xu L, Wang Y, Zhai C, Hao E: Apigenin Alleviates Endotoxin-Induced Myocardial Toxicity by Modulating Inflammation, Oxidative Stress, and Autophagy. Oxid Med Cell Longev 2017;2017:2302896.

45 Liu TT, Zeng Y, Tang K, Chen X, Zhang W, Xu XL: Dihydromyricetin ameliorates atherosclerosis in LDL receptor deficient mice. Atherosclerosis 2017;262:39-50.

46 Dong P, Pan L, Zhang X, Zhang W, Wang X, Jiang M, Chen Y, Duan Y, Wu H, Xu Y, Zhang P, Zhu Y: Hawthorn (Crataegus pinnatifida Bunge) leave flavonoids attenuate atherosclerosis development in apoE knock-out mice. J Ethnopharmacol 2017;198:479-488.

47 Cui Y, Hou P, Li F, Liu Q, Qin S, Zhou G, Xu X, Si Y, Guo S: Quercetin improves macrophage reverse cholesterol transport in apolipoprotein E-deficient mice fed a high-fat diet. Lipids Health Dis 2017;16:9.

48 Lee D, Shin C: MicroRNA-target interactions: new insights from genome-wide approaches. Ann N Y Acad Sci 2012;1271:118-128.

-49 Siasos G, Kollia C, Tsigkou V, Basdra EK, Lymperi M, Oikonomou E, Kokkou E, Korompelis P, Papavassiliou AG: MicroRNAs: Novel diagnostic and prognostic biomarkers in atherosclerosis. Curr Top Med Chem 2013;13:1503-1517.

50 Raitoharju E, Oksala N, Lehtimaki T: MicroRNAs in the atherosclerotic plaque. Clin Chem 2013;59:17081721.

-51 Feng X, Yu W, Li X, Zhou F, Zhang W, Shen Q, Li J, Zhang C, Shen P: Apigenin, a modulator of PPARgamma, attenuates HFD-induced NAFLD by regulating hepatocyte lipid metabolism and oxidative stress via Nrf2 activation. Biochem Pharmacol 2017;136:136-149.

52 He XW, Yu D, Li WL, Zheng Z, Lv CL, Li C, Liu P, Xu CQ, Hu XF, Jin XP: Anti-atherosclerotic potential of baicalin mediated by promoting cholesterol efflux from macrophages via the PPARgamma-LXRalpha-ABCA1/ ABCG1 pathway. Biomed Pharmacother 2016;83:257-264.

53 Ikhlef S, Berrougui H, Kamtchueng Simo 0, Khalil A: Paraoxonase 1-treated oxLDL promotes cholesterol efflux from macrophages by stimulating the PPARgamma-LXRalpha-ABCA1 pathway. FEBS Lett 2016;590:1614-1629.

54 Yang X, Li Y, Li Y, Ren X, Zhang X, Hu D, Gao Y, Xing Y, Shang H: Oxidative Stress-Mediated Atherosclerosis: Mechanisms and Therapies. Front Physiol 2017;8:600.

55 Cuaz-Perolin C, Billiet L, Bauge E, Copin C, Scott-Algara D, Genze F, Buchele B, Syrovets T, Simmet T, Rouis $\mathrm{M}$ : Antiinflammatory and antiatherogenic effects of the NF-kappaB inhibitor acetyl-11-keto-beta-boswellic acid in LPS-challenged ApoE-/- mice. Arterioscler Thromb Vasc Biol 2008;28:272-277.

-56 Liu R, Fan B, Cong H, Ikuyama S, Guan H, Gu J: Pycnogenol Reduces Toll-Like Receptor 4 Signaling Pathway-Mediated Atherosclerosis Formation in Apolipoprotein E-Deficient Mice. J Cardiovasc Pharmacol 2016;68:292-303.

57 Barua RS, Sharma M, Dileepan KN: Cigarette Smoke Amplifies Inflammatory Response and Atherosclerosis Progression Through Activation of the H1R-TLR2/4-COX2 Axis. Front Immunol 2015;6:572.

58 Han J, Chen D, Liu D, Zhu Y: Modafinil attenuates inflammation via inhibiting Akt/NF-kappaB pathway in apoE-deficient mouse model of atherosclerosis. Inflammopharmacology 2018; 26:385-393.

59 Falck-Hansen M, Kassiteridi C, Monaco C: Toll-like receptors in atherosclerosis. Int J Mol Sci 2013;14:14008-14023.

60 Xu XH, Shah PK, Faure E, Equils O, Thomas L, Fishbein MC, Luthringer D, Xu XP, Rajavashisth TB, Yano J, Kaul S, Arditi M: Toll-like receptor-4 is expressed by macrophages in murine and human lipid-rich atherosclerotic plaques and upregulated by oxidized LDL. Circulation 2001;104:3103-3108.

61 Lu Z, Zhang X, Li Y, Jin J, Huang Y: TLR4 antagonist reduces early-stage atherosclerosis in diabetic apolipoprotein E-deficient mice. J Endocrinol 2013;216:61-71. 


\section{Cellular Physiology Cell Physiol Biochem 2018;47:2170-2184

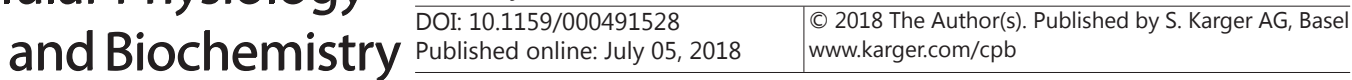 \\ Ren et al.: Apigenin Promotes ABCA1 Expression and Suppresses Inflammation}

62 Kim SJ, Park JH, Kim KH, Lee WR, Kim KS, Park KK: Melittin inhibits atherosclerosis in LPS/high-fat treated mice through atheroprotective actions. J Atheroscler Thromb 2011;18:1117-1126.

63 Luo H, Wang J, Qiao C, Ma N, Liu D, Zhang W: Pycnogenol attenuates atherosclerosis by regulating lipid metabolism through the TLR4-NF-kappaB pathway. Exp Mol Med 2015;47:e191.

-64 Liang C, Wang X, Hu J, Lian X, Zhu T, Zhang H, Gu N, Li J: PTPRO Promotes Oxidized Low-Density Lipoprotein Induced Oxidative Stress and Cell Apoptosis through Toll-Like Receptor 4/Nuclear Factor kappaB Pathway. Cell Physiol Biochem 2017;42:495-505.

-65 Zhao GJ, Tang SL, Lv YC, Ouyang XP, He PP, Yao F, Chen WJ, Lu Q, Tang YY, Zhang M, Fu Y, Zhang DW, Yin K, Tang CK: Antagonism of betulinic acid on LPS-mediated inhibition of ABCA1 and cholesterol efflux through inhibiting nuclear factor-kappaB signaling pathway and miR-33 expression. PLoS One 2013;8: e74782. 